ZOOLOGIA 32(5): 428-430, October 2015

http://dx.doi.org/10.1590/S1984-46702015000500012

\title{
Perilestes eustaquioi sp. nov. and new distributional records of Perilestidae (Odonata) in Brazil
}

\author{
Angelo B. M. Machado'
}

\begin{abstract}
${ }^{1}$ Departamento de Zoologia, Instituto de Ciências Biológicas, Universidade Federal de Minas Gerais. Caixa Postal 486, 31270-901 Belo Horizonte, MG, Brazil. Email: angelo@icb.ufmg.br
\end{abstract}

\begin{abstract}
Perilestes eustaquioi sp. nov. (holotype male deposited in ABMM collection) from the state of Bahia (municipality of Una), northeastern Brazil, is described and illustrated based on one male specimen. It differs from the other species of the genus mainly by the larger size of the anteclypeus in relations to the postclypeus. Together with $P$. fragilis Hagen in Selys, 1862 from the state of Sergipe and P. solutus Williamson \& Williamson, 1924 from the state of Ceará, these are the first records of Perilestidae from northeastern Brazil.
\end{abstract}

KEY WORDS. Biodiversity; damselflies; northeastern Brazil; Zygoptera.

Perilestidae contains 19 species in two Neotropical genera - Perilestes Hagen in Selys-Longchamps, 1862 and Perissolestes Kennedy, 1941 - distinguished by venational characters (GARRISON et al. 2010). With their characteristically long and slender abdomens, the habit of perching with the abdomen hanging vertically and secluded in dense forest habitats, the Perilestidae are often inconspicuous and easily overlooked. This probably explains the fact that they are rare in collections. Six unquestioned species of Perilestes occur in Brazil (Lencioni 2005), as described by Selys-Longchamps $(1862,1886)$, Kennedy (1941), Kimmins (1958), and Williamson \& Williamson (1924). The last described species dates from 57 years ago. Herein I describe a new species of Perilestes from the state of Bahia that, together with $P$. solutus Williamson \& Williamson, 1924 from the state of Ceará and $P$. fragilis Hagen in SelysLongchamps, 1862 from the state of Sergipe, constitute the first record of the Perilestidae from northeastern Brazil.

\section{MATERIAL AND METHODS}

The material examined consists of 1 male of Perilestes eustaquioi sp. nov. (holotype) collected in municipality of Una, state of Bahia (20-11-1987), Alvarenga leg.; 1 male of $P$. fragilis collected in Areia Branca municipality, state of Sergipe (VIII2014), Santos Jr. leg.; 5 males of $P$. solutus collected in Ubajara municipality, state of Ceará (VII-2014), Santos Jr. leg. Material deposited in ABM Machado collections at the Departamento de Zoologia, Instituto de Ciências Biológicas, Universidade Federal de Minas Gerais, Belo Horizonte. The proportion between the sizes of anteclypeus and postclypeus was taken at the midline of the sclerites. Abbreviations: (Px) postnodals, (Fw) forewing, (Hw) hind wing, (S1-10) abdomen segments 1 to 10 .

\section{TAXONOMY}

Perilestes eustaquioi sp. nov.

Figs. 1-5

Diagnosis. Cerci with a well developed basal lobe with rounded apex a character it shares only with $P$. fragilis, P. solutus and $P$. minor Williamson \& Williamson, 1924. It differs from these species by the color characters mentioned in Table 1 and by having the anteclypeus larger than the postclypeus.

Description. Holotype male. Head (Fig. 1). Labrum yellowish-white with the anterior $1 / 3$ black; anteclypeus yellowish-white with a black dot at its lateral limit with the labrum; postclypeus black; antefrons black with greenish reflections; upper part of head mostly metallic bluish-green, with black at the postfrons, occipital, and postocular areas.

Thorax. Propleuron yellow; pronotum with anterior and medial lobes brownish-yellow, posterior lobe yellowish-brown. Mesepisternum mostly reddish-brown, with a black narrow stripe adjacent to middorsal carina and a yellow antehumeral stripe occupying the lateral $1 / 4$ of the sclerite; acrotergal area black; mesepimeron reddish-brown, black at the inferior 1/10; mesinfraepisternum reddish-brown. Metapleuron yellow with a reddish-brown stripe at the $2^{\text {nd }}$ lateral suture. Pterothorax venter yellow with a median black stripe occupying its anterior $2 / 3$ and a reddish-brown lateral stripe occupying its posterior $1 / 3$. Wings hyaline; pterostigma dark brown. Venation: Px 9 in Fw and 8 in Hw; RP2 arising at $9^{\text {th }} \mathrm{Px}$ in Fw and at $8^{\text {th }}$ in Hw; IR1 arising distal to pterostigma in both wings; cells behind $\mathrm{CuA}$ in Fw 10 and in Hw 7.

Abdomen. S1 yellow; S2 dorsally dark brown, laterally yellow; S3-8 dorsally brown with a proximal yellow ring and a subapical yellow marking; S9 dorsally dark brown, laterally and posteriorly yellow; S10 dorsally orange brown, laterally yellow

2015 | Sociedade Brasileira de Zoologia | www.sbzoologia.org.br | www.scielo.br/zool

All content of the journal, except where identified, is licensed under a Creative Commons attribution-type BY. 

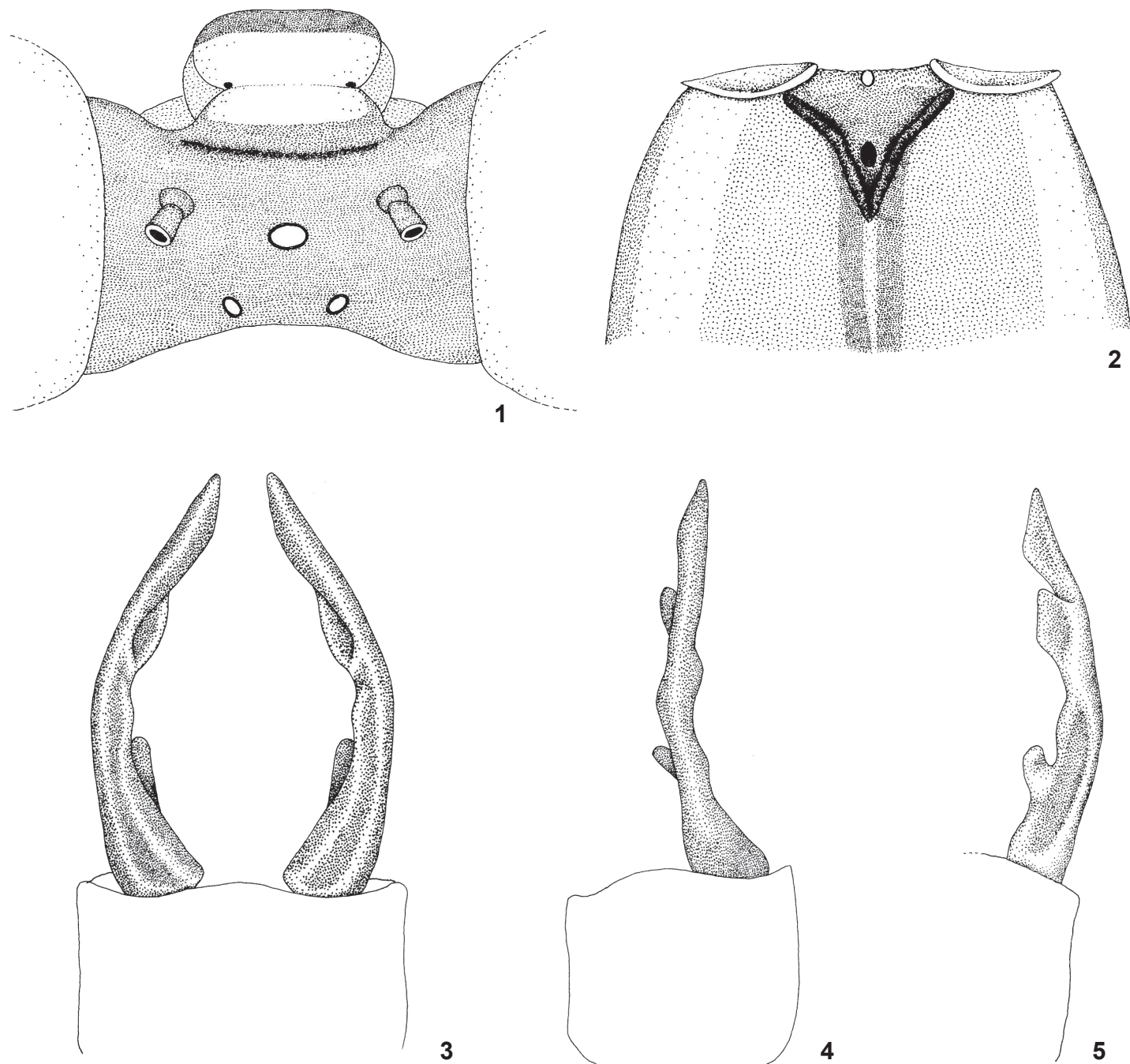

3
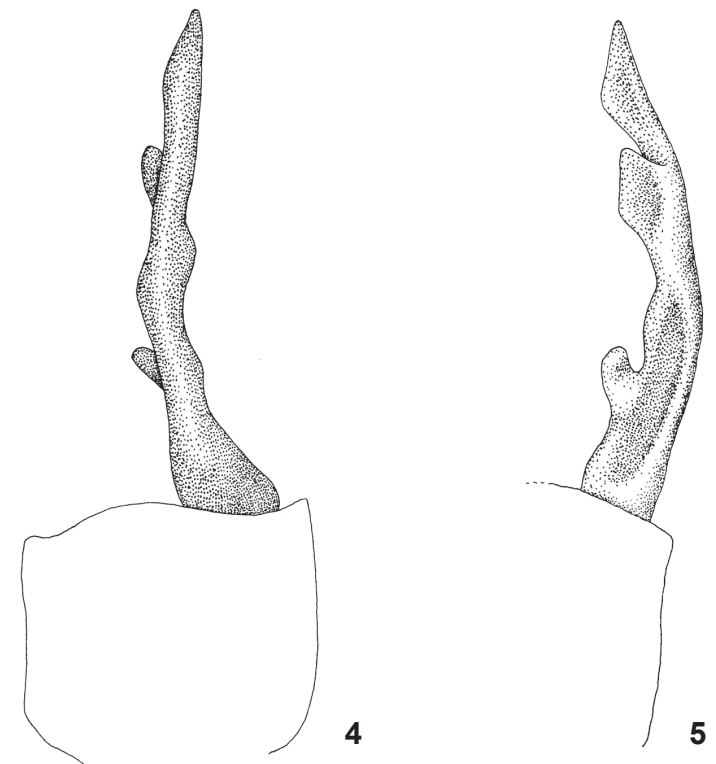

Figures 1-5. Perilestes eustaquioi sp. nov.: (1) head, dorsal view; (2) anterior part of pterothorax, dorsal view; (3-5) cerci: (3) dorsal, (4) lateral and (5) mediodorsal views.

Table 1. Color characters separating the males of Perilestes whose cerci have well developed basal lobe with rounded apex.

\begin{tabular}{|c|c|c|c|c|}
\hline Characters & P. eustaquioi sp. nov. & P. fragilis * & P. solutus * & P. minor * \\
\hline Labrum & Yellow, anterior $1 / 2$ black & Light blue, anterior $1 / 3$ black & $\begin{array}{l}\text { Bright blue, narrowly black } \\
\text { edged }\end{array}$ & Yellow, narrowly blue at base \\
\hline Anteclypeus & Yellowish-white & Blue & Blue & Bright blue \\
\hline Pale antehumeral stripe & $\begin{array}{l}\text { Not reaching the upper } \\
\text { part of sclerite }\end{array}$ & $\begin{array}{l}\text { Not reaching the upper part } \\
\text { of sclerite }\end{array}$ & $\begin{array}{l}\text { Reaching the upper part of } \\
\text { sclerite }\end{array}$ & Reaching the upper part of sclerite \\
\hline Venter of pterothorax & $\begin{array}{l}\text { With a black median and } \\
\text { two brown lateral stripes }\end{array}$ & $\begin{array}{l}\text { With a median and two } \\
\text { lateral black stripes }\end{array}$ & With a median black line & $\begin{array}{l}\text { With an anterior and a posterior black } \\
\text { spot }\end{array}$ \\
\hline S8-10 & Dark brown & Bright blue & Grey & Bright blue \\
\hline Cercus & Dark brown & White to brown & Dark reddish-brown & Dark reddish-brown \\
\hline Abdomen length (mm) & 50.6 & $50-52$ & $42-46$ & $40-41$ \\
\hline Hw length (mm) & 22.0 & $25-26$ & $20-21$ & 20 \\
\hline
\end{tabular}

${ }^{\star}$ Color characters according to WILLIAMSON \& WiLLIAMSON (1924). 
with a narrow orange red stripe just in front of the distal border. Cercus laterally black with distal $1 / 4$ brown; dorsally reddish-brown with proximal $1 / 3$ black.

Structural characters. Anteclypeus (Fig. 1) at its maximal extension medially subequal to postclypeus. Hind prothoracic lobe smoothly rounded. Mesostigmal plate concave, with a very small lateral projection (Fig. 2). Border of acrotergal area slightly elevated anteriorly with a small digitiform process that terminates behind the mesostigmal plate (Fig. 2).

Cercus: basal lobe in dorsal (Fig. 3), lateral (Fig. 4), and mediodorsal (Fig. 5) views with apex rounded, situated at $1 / 4$ distance from base to apex; distal lobe with base situated at 2/3 distance from base to apex; space between lobes smooth in lateral view (Fig. 4).

Measurements (mm). Abdomen 50.6, Hw 22.0.

Type material, Holotype male, BrAzIL, Bahia: Una (Reserva Biológica de Una), 20-II-1987, M. Alvarenga leg. Deposited in ABM Machado collection.

Etymology. This species is described in honor of my dear friend, biologist José Eustáquio Junior, who provided me a reach Odonata material, including specimens from Ceará and Sergipe.

Discussion. Perilestes eustaquioi sp. nov. belongs to the group of species whose cerci have a well developed basal lobe with rounded apex. This group comprises $P$. fragilis, $P$. minor Williamson \& Williamson, 1924, and $P$. solutus. Table 1 shows the main characters that allow the separation of these species.

Table 1 shows that the four species can be separated by color characters. Perilestes eustaquioi sp. nov. shares with $P$. fragilis the larger size. However, the most important character that separates $P$. eustaquioi sp. nov. from the other three, as well as from all other species of the genus, is the structure of the clypeus: in the new species the maximal extension medially of the anteclypeus is subequal to that of the postclypeus, whereas in the other ones the anteclypeus is about half the size of the postclypeus.

Zoogeographic considerations. The distribution map of Perilestes by GARrison et al. (2010) shows that the genus had never been recorded in a large portion of Brazil, encompassing the states of Amapá, east of Pará and the nine northeastern states. In addition to P. eustaquioi sp. nov., now described from the state of Bahia, I report the occurrence of two other species from northeastern Brazil: $P$. fragilis and $P$. solutus. They have been collected by the biologist José Eustáquio Santos Junior in localities of the states of Sergipe and Ceará, respectively, considerably expanding the distribution area of the genus. Northeastern Brazil is the country's most poorly studied region for dragonflies (DE MARCo \& Vianna 2005) and it is very likely that other Perilestes species will be found as the collecting effort increases in the region. Since Perilestes is a forest dweller, one would not expect northeastern Brazil to have a rich Perilestes fauna, for the dominant biome in the region is the semi-arid Caatinga, with xerophytic vegetation. The tropical rainforest areas (Atlantic Forest) are restricted to the coastal expanses and a few isolated altitudinal humid areas within the Caatinga, known as Brejos, where $P$. solutus was collected (Parque Nacional de Ubajara, Ceará). Perilestes fragilis was collected in remnants of the Atlantic Forest at the Parque Nacional da Serra de Itabaiana, Areia Branca, state of Sergipe.

\section{ACKNOWLEDGMENTS}

I thank Myrian Morato Duarte for the drawings of this paper. José Eustáquio Santos Junior collected the specimens from Ceará and Sergipe and Moacir Alvarenga who collected the holotype. I am also grateful to the biologist Lúcio Bedê for critically reviewing the manuscript.

\section{LITERATURE CITED}

De Marco Jr P, Vianna DM (2005) Distribuição do esforço de coleta de Odonata no Brasil - subsídios para escolha de áreas prioritárias para levantamentos faunísticos. Lundiana 6 (Supp.): 13-26.

Garrison RW, von Ellenrieder N, Louton JA (2010) Damselfly genera of the New World: an illustrated and annotated key to the Zygoptera. Baltimore, Johns Hopkins University Press, 490p.

Kennedy CH (1941) Perilestinae in Ecuador and Peru, revisional notes and descriptions (Lestidae: Odonata). Annals of the Entomological Society of America 34(3): 658-688.

Kimmins DE (1958) New species and subspecies of Odonata. Bulletin of the British Museum (Natural History), Entomology 7(7): 349-358.

LENCIONI FAA (2005) Damselflies of Brazil: an illustrated identification guide. São Paulo, All Print Editora, vol. 1, 324p.

Selys-Longchamps ME de (1862) Synopsis des Agrionines. Troisième légion: Podagrion. Bulletins de l'Académie Royale des Sciences, des Lettres et des Beaux-Arts de Belgique (2me série) 14(6): 5-44.

Selys-Longchamps ME de (1886) Revision du synopsis des Agrionines, première partie comprenant les légions Pseudostigma - Podagrion - Platycnemis et Protoneura. Memoires Couronnées Académie Royale de Belgique 38(4): I-IV, 233p.

Williamson EB, Williamson JM (1924) The genus Perilestes (Odonata). Miscellaneous Publication, Museum of Zoology, University of Michigan 14: 1-39.

Submitted: 4 May 2015

Received in revised form: 24 September 2015

Accepted: 25 September 2015

Editorial responsibility: Gabriel L.F. Mejdalani 